\title{
Can the peak discharge-total volume relationship for flow pulses be used to identify flow regime change?
}

\author{
$\underline{\text { J.F. Costelloe }}^{\mathrm{a}}$, C. Pilkington ${ }^{\mathrm{b}}$ and P. Rice ${ }^{\mathrm{c}}$ \\ ${ }^{a}$ Department of Infrastructure Engineering, University of Melbourne, Victoria, 3010 \\ ${ }^{b}$ Aurecon, Cairns, Queensland, 4870 \\ ${ }^{c}$ Kleinfelder, Melbourne, Victoria, 3205 \\ Email: jcost@unimelb.edu.au
}

\begin{abstract}
A significant relationship between the peak discharge $\left(\mathrm{Q}_{\mathrm{p}}\right)$ and total volume $\left(\mathrm{V}_{\mathrm{T}}\right)$ of a flow pulse has been well established by a number of studies. This relationship can be expressed as a power law function (e.g. $Q_{p}=b V_{T}{ }^{m}$, where $b$ and $m$ are parameters determined by calibration) and has been shown to be useful for determining the hydrologic linearity or non-linearity of catchments, identifying regional similarities between basins and estimating peak discharges. We further explore this relationship to determine whether it is most influenced by hillslope or channel storage processes and if it can be used to identify changes in catchment behaviour resulting from land-use change. The analysis uses streamflow data from ephemeral to intermittent catchments that range in scale from $<1 \mathrm{~km}^{2}$ to $>10,000 \mathrm{~km}^{2}$ and with some of these catchments being subject to well-defined, large-scale land-use change. The relationship between peak discharge and total volume of flow pulses was found to be only moderately correlated for micro-catchments (e.g. $<1 \mathrm{~km}^{2}$ ) and showed stronger correlations for larger catchments. Linear regression of $\log _{10}$-transformed data and the non-parametric Kolmogorov-Smirnov test were applied to the flow pulse data to identify if land use changes resulted in statistically significant differences in the characteristics of the flow pulses. The changes in these characteristics in the microcatchments were found to be generally significant but similar changes also occurred in an uncleared control catchment. In the larger catchments, differences in the linear regression coefficients between pre- and post-land clearing periods were only significant at the $95^{\text {th }}$ percentile confidence interval for small flows. The Kolmorogov-Smirnov test showed that some catchments experienced 'flashier' flow pulses (i.e. higher peak discharges for a given total volume and shorter durations) following catchment clearing. The variations in response between microcatchments $\left(<1 \mathrm{~km}^{2}\right)$ compared to larger catchments $\left(>3 \mathrm{~km}^{2}\right)$ may reflect that the flow pulse characteristics are less sensitive to changes in hillslope land use compared to changes in the storage characteristics of the channel network in larger catchments. The analysis of the flow pulse characteristics makes use of observed data and provides an additional means of evaluating catchment responses to changes (e.g. climatic or to catchment characteristics), in addition to other commonly used analysis techniques, such as flow duration curves.
\end{abstract}

Keywords: $\quad$ Land use change, linear regression, catchment scale 
Costelloe et al., Can the peak discharge-total volume relationship for flow pulses be used to identify flow regime change?

\section{INTRODUCTION}

\subsection{Identifying flow regime change}

Critical to our understanding of the health of a catchment is to determine if the flow regime has changed due to anthropogenic influences, by how much and in what direction (Poff et al., 1997; Richter et al., 1997). The influence of land-use change on the hydrological response of a catchment has been widely studied over a range of climatic, geographic and topographic conditions (Bosch and Hewlett, 1982; Zhang et al., 2001; Siriwardena et al., 2006). The identification of flow regime change is particularly problematic for ephemeral and intermittent streams with highly variable flow regimes. In such systems, human-induced change can be difficult to separate from the natural variability in streamflow patterns. Appropriate methods are required to identify changes in the flow regime caused by changes in land use and catchment storage. The methods need to be able to cope with the relatively short ( $<20-30$ years) flow records and data gaps that are common for many ephemeral and intermittent streams in Australia. Given the relative paucity of streamflow data in many semi-arid to arid catchments, it is important that data-driven methods of flow regime change make the most of the available data.

A significant relationship between the peak discharge and total volume of a flow event has been well established by a number of studies (Rogers, 1980; Mimikou, 1982; Singh and Aminian, 1986). This relationship has been shown to be useful for a variety of purposes, such as determining the hydrologic linearity or non-linearity of catchments, identifying regional similarities between basins and estimating peak discharges (Rogers, 1980; Singh and Aminian, 1986). In terms of assessing changes in flow regime, this relationship has the advantages of involving observed data and a flow characteristic with hydrologic and ecological relevance, the flow pulse. The analysis of this relationship is also well suited to intermittent to ephemeral flow regimes. In this paper, we further explore this relationship to determine whether it is most influenced by hillslope or channel storage processes and if it can be used to identify changes in catchment behaviour resulting from land-use change.

\subsection{The peak discharge - total volume relationship}

Power laws relating measures of streamflow to catchment and climatic characteristics are well documented and have been used for water resource analysis. For instance, the peak discharges of specified return periods and mean annual runoff volumes have been related to the drainage area (Goodrich et al., 1997). Power laws have also been observed for event-based relationships, such as between drainage area and the peak discharge and maximum volume of flow events (Meirovich et al., 1998; Furey and Gupta, 2007). The relationship between peak discharge $\left(Q_{p}\right)$ and total volume $\left(V_{T}\right)$ of an individual flow pulse was first defined by Rogers (1980) in log space as:

$$
\log Q_{P}=\log b+m \log V_{T}
$$

where $b$ and $m$ are calibrated through regression analysis of peak discharge and total volume data. The same relationship can also be expressed as a power law of the form:

$$
Q_{p}=b V_{T}^{m}
$$

The power coefficient $m$ (dimensionless) provides a measure of the 'linearity' of a catchment's streamflow response (Rogers, 1980). The coefficient $b$ (units of 1/T) is significantly related to measures of the catchment morphology; primarily catchment area but also to main stream length and average bedslope of the stream (Mimikou, 1983; Singh and Aminian, 1986). In large arid zone catchments with long channel reaches, this relationship (2) between the peak discharge and total volume of flow events has been found to be significantly correlated (Knighton and Nanson, 2001). However, changes in this relationship with varying catchment scale have not been rigorously examined, in particular, the change in relationship from a small catchment, where the flow pulse characteristics are dominated by the hillslope storage and travel time, to a larger catchment, where the flow pulse characteristics are dominated by channel storage and travel time, are not well understood. These correlations suggest that $b$ is sensitive to the mean travel time of catchment outflow and so may also be affected by additional variable catchment conditions (e.g. hillslope and channel mean roughness) other than invariant measures such as catchment area.

The sensitivity of parameters $b$ and $m$ to changes in catchment condition has not been previously investigated. We hypothesise that the peak discharge - total volume relationship for flow pulses in a given catchment can be used to identify temporal changes in catchment response due to changes in land use (e.g. deforestation) and condition. 
Costelloe et al., Can the peak discharge-total volume relationship for flow pulses be used to identify flow regime change?

Following a diagnostic framework for understanding space-time hydrologic patterns advocated by Furey and Gupta (2007), we follow these steps:

1. Identify and quantify a recurring space-time pattern in observed data, in this case the consistency of the peak discharge - total volume relationship for flow events in ephemeral streams across different scales and geographic regions.

2. Use datasets to qualitatively show how conditions and processes influence the pattern, i.e., for catchments with a highly correlated $\mathrm{Q}_{\mathrm{p}}$ and $\mathrm{V}_{\mathrm{T}}$ relationship, does this significantly vary following changes in land use or catchment storage?

\section{METHODS}

\subsection{Study catchments}

Four groups of ephemeral to intermittent catchments, comprising eleven individual catchments, were chosen from semi-arid to arid regions for the analysis. The catchments range from small paired experimental catchments with well-studied responses to specific land use changes, to a large natural catchment with long term land use change. Ephemeral to intermittent catchments were chosen to avoid the effects of significant baseflow on the flow pulse characteristics. The catchments ranged from $<0.2 \mathrm{~km}^{2}$ to $16400 \mathrm{~km}^{2}$ and periods of data availability are shown in Table 1.

The Brigalow catchments are situated in central Queensland and comprise three experimental catchments with areas ranging from 0.12 to $0.17 \mathrm{~km}^{2}$ (www.nrm.qld.gov.au/science/projects/brigalow). The catchments are situated in the Fitzroy River Basin and experience a semi-arid climate with mean annual rainfall of 707 $\mathrm{mm}$, mean annual temperature of $21.4{ }^{\circ} \mathrm{C}$ and summer seasonal rainfall. The catchments have been monitored for precipitation and streamflow discharge since 1965 and land use treatments were conducted on two of the catchments during 1982. Prior to land clearing, the catchments contained 'brigalow scrub' - open woodland dominated by Acacia harpophylla (brigalow). One of the catchments remained uncleared as a control catchment and the other two were cleared and converted to cropping and pasture, respectively.

The Collie catchments are experimental catchments located in the Collie River Basin of southwestern Western Australia. They have catchment areas of approximately $3.5 \mathrm{~km}^{2}$ and have intermittent, winter-spring dominant streamflow and a mean annual rainfall of $712 \mathrm{~mm}$. The catchments have streamflow records from 1974 to 2004 and were partially cleared of native forest in 1976.

The Walnut Gulch catchments are situated in Arizona, southwestern USA and have a total area of $150 \mathrm{~km}^{2}$. They are a series of nested, ephemeral, experimental catchments run by the United States Department of Agriculture and occur in a semi-arid climate with a mean annual rainfall of $350 \mathrm{~mm}$. Most runoff events are generated by convective thunderstorms during the summer period (Goodrich et al., 1997). There has been no substantial land-use change during the period of monitoring.

The Comet River catchment is located in central Queensland and has a catchment area of $16400 \mathrm{~km}^{2}$. The catchment is situated in a semi-arid climate with a mean annual rainfall of $660 \mathrm{~mm}$. The catchment underwent large scale land clearing from 1960-1970 and a period farm dam development since 1965 (Siriwardena et al., 2006). Discharge data for the period of 1919-2002 are available from a gauging station located near the end of the catchment.

\subsection{Flow pulse characteristics}

The daily or sub-daily discharge record of each available gauging station was used to automatically identify individual flow pulses using spreadsheet algorithms. In many cases, the proceeding flow pulse truncated the recession of the preceding flow pulse (Figure 1). A flow duration threshold of greater than two days for the larger catchments was used to remove the more obviously truncated flow events from the record. Characteristics of flow pulses, such as peak discharge, total volume, total duration, duration of rising stage and falling stage, were extracted for all defined pulses. Compound pulses were also defined that incorporated all pulses above a defined base level of flow (e.g. zero flow in the more ephemeral catchments) into a single pulse (see Figure 1). For these compound pulses, $\mathrm{Q}_{\mathrm{p}}$ was the maximum discharge for the period above the base discharge and $\mathrm{V}_{\mathrm{T}}$ was the total volume for that period (i.e. summing the volumes of all subsidiary pulses within the compound pulse).

The $\mathrm{Q}_{\mathrm{p}}$ and $\mathrm{V}_{\mathrm{T}}$ data were $\log _{10}$ transformed and linear regression analysis was conducted on the entire dataset for each catchment and also on the pre-change and post-change periods for each catchment. Differences in 
Costelloe et al., Can the peak discharge-total volume relationship for flow pulses be used to identify flow regime change?

the linear regression between the two periods were tested at the $95^{\text {th }}$ percentile confidence levels. The ratio of the peak discharge $\left(\mathrm{Q}_{\mathrm{p}}\right)$ to total volume $\left(\mathrm{V}_{\mathrm{T}}\right)$, duration of flow and duration of rising and falling stages were calculated for all pulses over the two periods and statistically tested to see if they were significantly different. The $\mathrm{Q}_{\mathrm{p}} / \mathrm{V}_{\mathrm{T}}$ ratio data generally had a positive skewness, probably due to the presence of truncated flow pulses in the dataset, and the flow duration data showed strongly positive skews more consistent with a gamma distribution. Given the lack of normal distribution in the $\mathrm{Q}_{\mathrm{p}} / \mathrm{V}_{\mathrm{T}}$ ratio and duration datasets, the two-sample Kolmogorov-Smirnov test was used to identify significant shifts in the distribution of the data (Press et al., 2002).

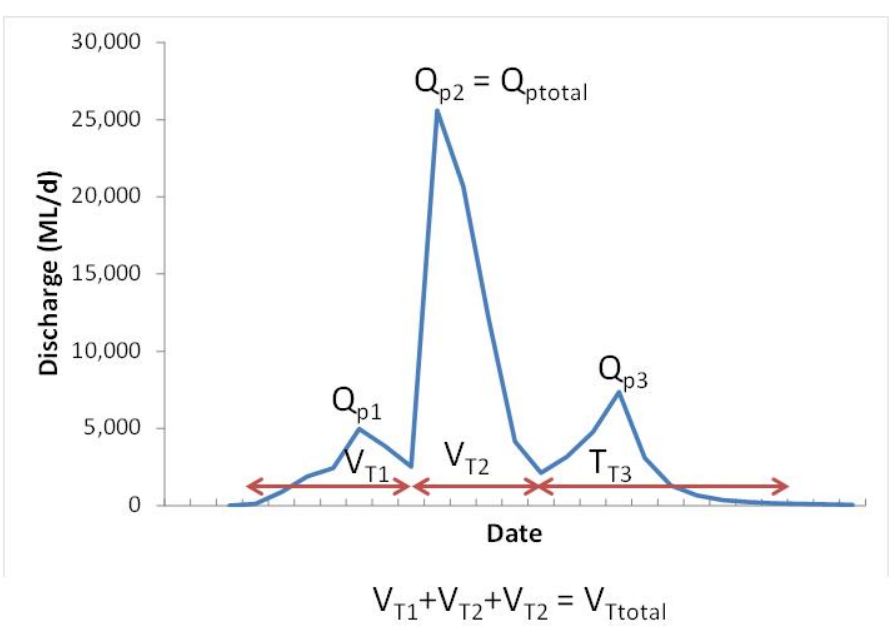

Figure 1. Flow pulse characteristics shown for a series of three single pulses and a compound pulse.

\section{RESULTS}

\subsection{Scale dependency}

The relationship between $\mathrm{Q}_{\mathrm{p}}$ and $\mathrm{V}_{\mathrm{T}}$ showed increasing correlation with increasing catchment area for all pulses (see adjusted $\mathrm{R}^{2}$ values in Table 1). There appears to be a threshold effect, with microcatchments (i.e. $<1 \mathrm{~km}^{2}$ ) having a marked decrease in correlation compared to larger catchments. The larger catchments do not show an obvious improvement in correlation with increasing area. This may be partly obscured by only having one very large catchment (Comet River) and regional differences. For instance, the Walnut Gulch data show a range of $\mathrm{R}^{2}$ values between $0.82-0.90$ and are lower than the smaller Collie catchments and the much larger Comet River catchment. The threshold effect for microcatchments is also shown by the increase in the correlation when considering compound pulses (e.g. beginning and ending at zero flow) in comparison to all pulses for the Brigalow and Walnut Gulch catchments. The compound pulses are likely to integrate the whole of catchment response while the individual pulses are more likely to include responses from different parts of the catchment, particularly the initial response. The poorer correlation using all pulses also reflects the higher number of shortened, or spurious, flow pulses caused by minor fluctuations in the flow rate resulting in the resetting of flow pulses. However, for the Walnut Gulch catchments, there was no consistent or substantial improvement in the relationship using the compound pulses. The difference in temporal scale was also investigated by calculating pulses using hourly and daily data for the Collie catchments. The smoothing effect of using daily data resulted in only minor increases in correlation compared to the hourly data.

\subsection{Sensitivity to land-use changes}

The three Brigalow experimental catchments all showed a consistent change in flow pulse characteristics between the pre-change (1965-1981) and post-change (1984-2004) periods with a decrease in the power coefficient $(m)$ and an increase in the $b$ parameter (Table 2). This would suggest a quickening in catchment response time and an increase in the non-linearity of catchment response, with these changes being consistent with expectations of the effects of the land use change; specifically faster runoff. However, the changes in the 
Costelloe et al., Can the peak discharge-total volume relationship for flow pulses be used to identify flow regime change?

linear regressions at the $95^{\text {th }}$ percentile were only significant for smaller flow pulses, with the 'pasture' catchment showing the largest change and the 'cropping' catchment showing the smallest change. The Kolmogorov-Smirnov test showed a significant change $(\mathrm{p}<0.005)$ in the distribution of the $\mathrm{Q}_{\mathrm{p}} / \mathrm{V}_{\mathrm{T}}$ ratio between the two periods for the three catchments, indicating that the post-change period had steeper (i.e. higher $\mathrm{Q}_{\mathrm{p}} / \mathrm{V}_{\mathrm{T}}$ ratio) flow pulses. Given that the uncleared control catchment showed a similar direction in change to the two cleared catchments, and midway in magnitude, this indicated that the observed changes in the flow pulses probably reflected changes in climatic inputs (e.g. precipitation characteristics or long term soil moisture variations) or were within the uncertainty of the relationship, rather than due to catchment clearing.

Table 1. Linear regression correlation between $\log _{10}$ transformed $Q_{p}$ and $V_{T}$ across a range of catchment scales. All correlations significant at $\mathrm{p}<0.001$. *Measured using daily discharge data in comparison to hourly discharge data used to measure all pulses at Collie catchments.

\begin{tabular}{|c|c|c|c|c|c|c|c|}
\hline Region & Catchment & Period & Pre-change & $\begin{array}{l}\text { Post- } \\
\text { change }\end{array}$ & $\begin{array}{c}\text { Area } \\
\left(\mathrm{km}^{2}\right)\end{array}$ & $\begin{array}{c}\text { Adjusted } \mathrm{R}^{2}-\text { all } \\
\text { pulses }\end{array}$ & $\begin{array}{c}\text { Adjusted } R^{2}- \\
\text { compound } \\
\text { pulses }\end{array}$ \\
\hline \multirow[t]{2}{*}{ Brigalow } & Control & $1965-2004$ & $1965-1981$ & $1984-2004$ & 0.17 & 0.45 & 0.87 \\
\hline & Pasture & $1965-2004$ & $1965-1981$ & $1984-2004$ & 0.13 & 0.42 & 0.77 \\
\hline Collie & 612007 (Dons) & 1974-2004 & 1974-1975 & $1978-2004$ & 3.50 & 0.93 & $0.98 *$ \\
\hline Walnut & Flume 3 & 1999-2006 & & & 8.98 & 0.89 & 0.93 \\
\hline \multirow[t]{4}{*}{ Gulch } & Flume 7 & $1999-2006$ & & & 13.52 & 0.89 & 0.91 \\
\hline & Flume 9 & 1999-2006 & & & 23.59 & 0.88 & 0.82 \\
\hline & Flume 2 & 1999-2006 & & & 113.72 & 0.90 & 0.87 \\
\hline & Flume 1 & $1999-2006$ & & & 149.33 & 0.82 & 0.89 \\
\hline
\end{tabular}

The Collie catchments showed relatively small decreases in the $m$ parameter, small increases in the $b$ parameters and a small decrease in the $\mathrm{R}^{2}$ values for the post-change period (1978-2004) compared to the pre-change period (Table 2). This was similar in trend to the changes shown in the Brigalow catchments. However, the differences between the pre and post-change regressions were only significant for small flows at the $95^{\text {th }}$ percentile confidence level (e.g. Figure 2). The Kolmogorov-Smirnov test of the daily data showed significant differences $(\mathrm{p}<0.001)$ in the distribution of the $\mathrm{Q}_{\mathrm{p}} / \mathrm{V}_{\mathrm{T}}$ ratio data between the two periods for the Lemon catchment but no significant differences $(p>0.1)$ for the Dons catchment (Figure 2). The analysis of change for these catchments may be hindered by the much shorter pre-change period (1974-1975) compared to the post change period (1978-2004).

The much larger Comet catchment showed the opposite trend in parameter values between the two periods compared to the smaller cleared catchments (Table 2). However, differences were not significant at the $95^{\text {th }}$ percentile confidence level in the $\log _{10}$ linear regression between the pre-change period (1919-1959) and the post-change period (1971-2002). However, the Kolmogorov-Smirnov test showed a significant change $(\mathrm{p}<0.001)$ in the distribution of the $\mathrm{Q}_{\mathrm{p}} / \mathrm{V}_{\mathrm{T}}$ ratio between the two periods, with ratios in the $10^{\text {th }}$ to $90^{\text {th }}$ percentile range showing larger values (i.e. 'steeper' flow pulses) in the post-change period (Figure 2). Analysis of the flow duration and duration of the falling limb of flow pulses between the two periods also showed a significant change $(\mathrm{p}=0.007, \mathrm{p}=0.047$ respectively) with durations decreasing in the post-change period. These non-parametric test results are consistent with flow pulses becoming 'flashier' following widespread catchment clearance.

Table 2. Linear regression correlation and parameter values for $\log _{10}$ transformed $\mathrm{Q}_{\mathrm{p}}$ and $\mathrm{V}_{\mathrm{T}}$ between preclearing and post-clearing periods. All correlations significant at $\mathrm{p}<0.001$.

\begin{tabular}{|c|c|c|c|c|c|c|c|c|}
\hline \multirow[b]{2}{*}{ Catchment } & \multirow[b]{2}{*}{$\begin{array}{l}\text { Area } \\
\left(\mathbf{k m}^{2}\right)\end{array}$} & \multicolumn{3}{|c|}{ Pre-treatment } & \multicolumn{3}{|c|}{ Post-treatment } & \multirow[b]{2}{*}{$\begin{array}{l}\text { Sign. Diff. at } \\
95^{\text {th }} \text { percentile }\end{array}$} \\
\hline & & $\log (b)$ & m & $\mathbf{R}^{2}$ & $\log (b)$ & & $\mathbf{R}^{2}$ & \\
\hline Brigalow -control & 0.17 & -2.679 & 0.581 & 0.850 & -1.937 & 0.451 & 0.541 & Yes \\
\hline Brigalow -cropping & 0.12 & -2.640 & 0.579 & 0.781 & -2.333 & 0.531 & 0.566 & No \\
\hline Brigalow -pasture & 0.13 & -2.489 & 0.549 & 0.740 & -1.483 & 0.258 & 0.164 & \\
\hline Collie - 612007 & 3.50 & -0.841 & 0.923 & 0.949 & -0.754 & 0.899 & 0.931 & \\
\hline Collie - 612009 & 3.44 & -0.747 & 0.932 & 0.924 & -0.690 & 0.891 & 0.899 & \\
\hline Comet & 16400 & -0.277 & 0.916 & 0.958 & -0.303 & 0.934 & 0.956 & No \\
\hline
\end{tabular}


Costelloe et al., Can the peak discharge-total volume relationship for flow pulses be used to identify flow regime change?

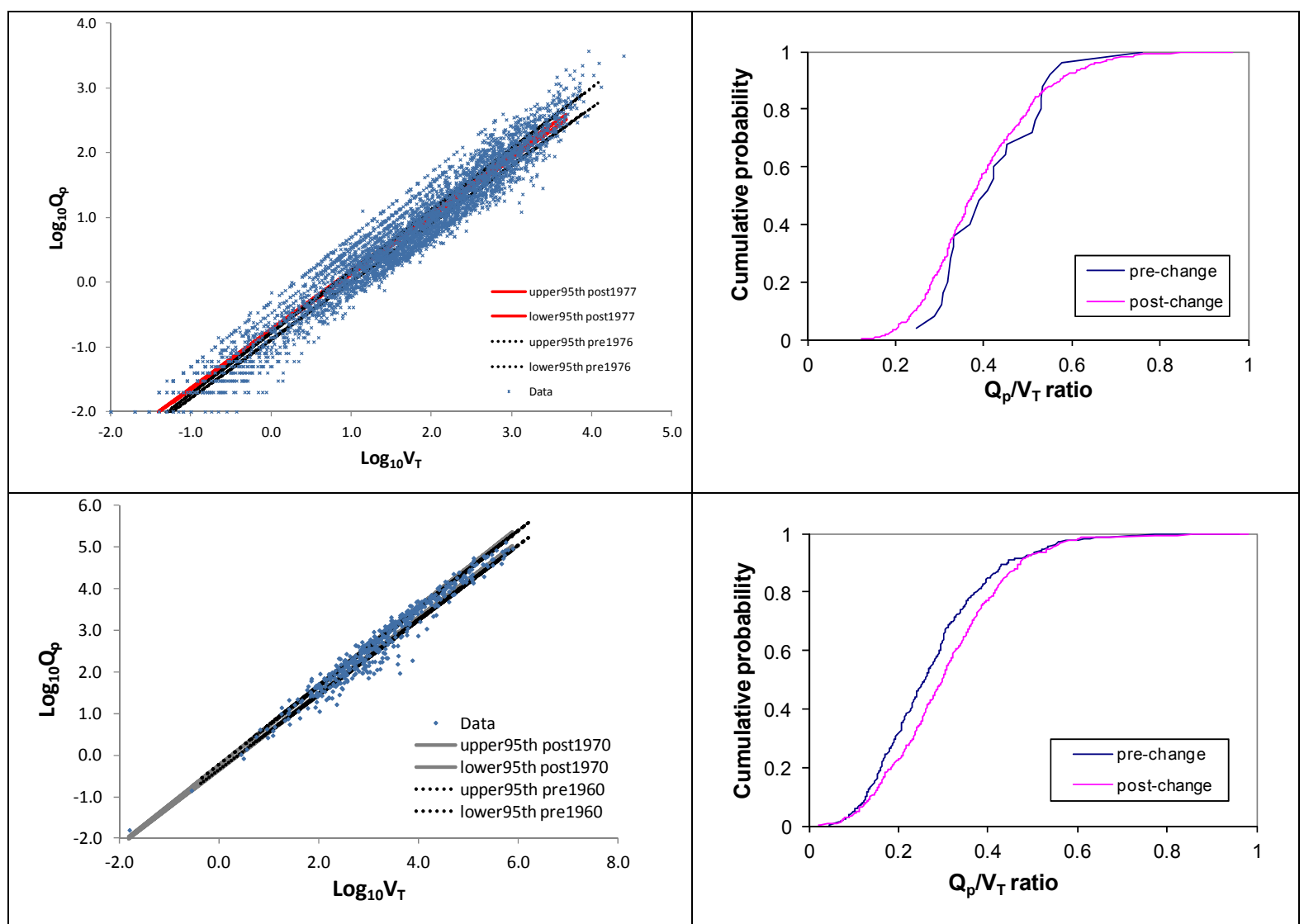

Figure 2. $\log _{10}$-transformed regression and cumulative probability distribution of $\mathrm{Q}_{\mathrm{p}}$ and $\mathrm{V}_{\mathrm{T}}$ data for the prechange and post-change periods in the Collie (612007 - Dons, top panels) and Comet (bottom panels) catchments.

\section{DISCUSSION AND CONCLUSION}

The relationship between peak discharge and total volume of flow events is least correlated for microcatchments of area $<1 \mathrm{~km}^{2}$ but is typically strongly correlated for catchment areas of $>3 \mathrm{~km}^{2}$, possibly reflecting the change in dominance between hillslope and channel processes. Goodrich et al. (1997) observed that the average ratio of channel area to drainage area in ephemeral catchments at Walnut Gulch was considerably less for catchments of area $<0.37 \mathrm{~km}^{2}$ and that the relationship between mean annual runoff and catchment area became more non-linear for catchments of area $>0.60 \mathrm{~km}^{2}$. Robinson et al. (1995) demonstrated that theoretical catchment response for overland flow dominated catchments changes at a threshold area of approximately $2 \mathrm{~km}^{2}$. The observed change in this study of the improved correlation in the peak discharge and total volume relationship implies that the relationship is more highly associated with channel processes rather than hillslope processes.

The sensitivity of the $\mathrm{Q}_{\mathrm{p}} / \mathrm{V}_{\mathrm{T}}$ relationship to land-use changes, specifically clearing of native vegetation for cropping and grazing, is moderate. Changes in the relationship in the catchments that underwent clearing were consistent with expected outcomes, with flow pulses tending to be steeper and of shorter duration in the post-clearing period. These changes were more easily identified using the non-parametric KolmogorovSmirnov test to identify changes in the distribution of flow pulse characteristics (i.e. $\mathrm{Q}_{\mathrm{p}} / \mathrm{V}_{\mathrm{T}}$ ratio, duration) than in comparing changes in the linear regression of the $\log _{10}$ transformed $\mathrm{Q}_{\mathrm{p}}$ and $\mathrm{V}_{\mathrm{T}}$ data. However, the similar changes observed in the Brigalow control catchment compared to the neighbouring cleared catchments suggests that other temporal characteristics (e.g. climate inputs) can also result in changes to the flow pulse characteristics. This may also reflect that the flow pulse characteristics are less sensitive to changes in hillslope land use compared to changes in the storage characteristics of the channel network in larger catchments. Accounting for other temporal controls on the flow pulse relationship, such as changes in rainfall intensity or variations in storm tracks (particularly over small catchments), would require additional 
Costelloe et al., Can the peak discharge-total volume relationship for flow pulses be used to identify flow regime change?

meteorological information and careful vetting of the flow pulses to separate them into groups with similar storm behavior. Certainly, the decrease in $\mathrm{R}^{2}$ values in the post-treatment period for all Brigalow catchments suggests that these non-land use factors can have a large effect on the flow pulse relationship. The analysis of the flow pulse characteristics makes use of observed data and provides an additional means of evaluating catchment responses to changes (e.g. climatic or to catchment characteristics), in addition to other commonly used analysis techniques, such as flow duration curves.

\section{ACKNOWLEDGMENTS}

Data sets for the Brigalow catchments were provided by the Brigalow Catchment Study project, a project managed by the Department of Natural Resources and Water and located on the Department of Primary Industries and Fisheries Brigalow Research Station via Theodore, Queensland, Australia. Data sets for the Collie catchments were provided courtesy of the Western Australian Department of Water. Data sets for the Walnut Gulch catchments were provided courtesy of the United States Department of Agriculture (http://www.tucson.ars.ag.gov/dap/). Data set for the Comet River Catchment was provided courtesy of the Queensland Department of Natural Resources and Mines.

\section{REFERENCES}

Bosch, J.M., and J.D. Hewlett (1982). A review of catchments to determine the effects of vegetation changes on water yield and evapotranspiration. Journal of Hydrology, 55, 3-23.

Furey, P.R., and V.K. Gupta (2007). Diagnosing peak discharge power laws observed in rainfall runoff events in Goodwin Creek experimental watershed. Advances in Water Resources, 30, 2389-2399.

Goodrich, D.C., L.J. Lane, R.M. Shillito, S.N. Miller, K.R. Syed and D.A. Woolhiser (1997). Linearity of basin response as a function of scale in a semiarid watershed. Water Resources Research, 33, 2951-2965.

Lane, P.N.J., A.E. Best, K. Hickel and L. Zhang (2005). The response of flow duration curves to afforestation. Journal of Hydrology, 310, 253-265.

Meirovich, L., A. Ben-Zvi, I. Shentsis and E. Yanovich (1998). Frequency and magnitude of runoff events in the arid Negev of Israel. Journal of Hydrology, 207, 204-219.

Mimikou, M. (1982). A study of drainage basin linearity and non-linearity. Journal of Hydrology, 64, 113134.

Molfino, M.E., and J.F. Cruise (1990). An additional analysis of peak-volume relations and standardization procedures. Water Resources Bulletin, 26, 687-692.

Poff, N.L., J.D. Allan, M.B. Bain, J.R. Darr, K.L. Pretegaard, B.D. Richter, R.E. Sparks and J.C. Stromberg (1997). The natural flow regime: a paradigm for river conservation and restoration. Bioscience, 47, 769784.

Press, W.H., S.A. Teukolsky, W.T. Vetterling and B.P. Flannery (2002). Numerical Recipes in C++: the art of scientific computing. Second edition, Cambridge University Press, Cambridge, pp.1002.

Richter, B.D., J.V. Baumgartner, R. Wigington and D.P. Braun (1997). How much water does a river need? Freshwater Biology, 37, 231-249.

Robinson, J.S., M. Sivapalan and J.D. Snell (1995). On the relative roles of hillslope processes, channel routing, and network geomorphology in the hydrologic response of natural catchments. Water Resources Research, 31 (3), 3089-3101.

Rogers, W.F. (1980). A practical model for linear and nonlinear runoff. Journal of Hydrology, 46, 51-78.

Singh, V.P., and H. Aminian (1986). An empirical relation between volume and peak of direct runoff. Water Resources Bulletin, 22, 725-730.

Siriwardena, L., B.L. Finlayson and T.A. McMahon (2006). The impact of land use change on catchment hydrology in large catchments: The Comet River, Central Queensland, Australia. Journal of Hydrology, 326, 199-214.

Zhang, L., W.R. Dawes and G.R. Walker (2001). Response of mean annual evapotranspiration to vegetation changes at catchment scale. Water Resources Research, 37 (3), 701-708. 